\title{
Summary Status on the Seismic Evaluations of Hanford Site Radioactive Waste Storage Tanks
}

D. L. Becker

R. A. Marusich

J. A. Ryan

D. A. Smith

A. M. Tallman

G. R. Wagenblast

Date Published

September 1990

Prepared for the U.S. Department of Energy Office of Environmental Restoration and Waste Management

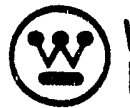

\section{Westingthouse}

Hantord Company Richland, Washington 99352

Hanford Operations and Engineering Contractor tor the

U.S. Department of Energy under Contract DE-AC06-87RL10930 
TABLE OF CONTENTS

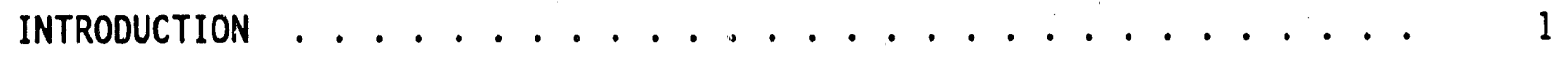

SEISMIC DESIGN CRITERIA . . . . . . . . . . . . . . 7

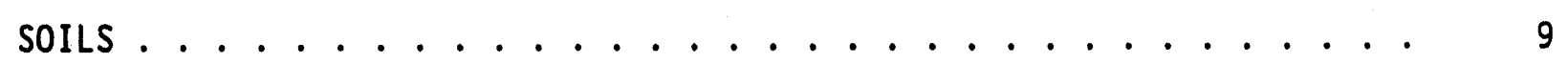

SINGLE-SHELL TANK SEISMIC EVALUATIONS . . . . . . . . . . . . 9

DOUBLE-SHELL TANK SEISMIC EVALUATIONS . . . . . . . . . . . 11

WASTE TANK SAFETY-RELATED EqUIPMENT . . . . . . . . . . . . . 14

PLANNED ACTIVITIES . . . . . . . . . . . . . . . . . 14

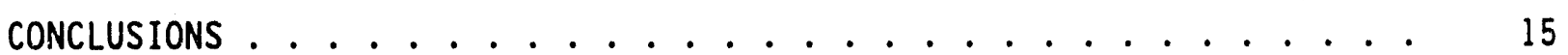

SINGLE-SHELL TANKS ................ 15

DOUBLE-SHELL TANKS .................... 15

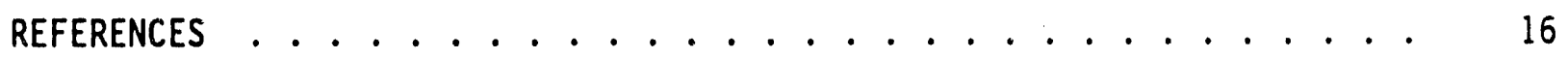

DESIGN CRITERIA REFERENCES (TABLES 1 AND 2) . . . . . . . . . . 19

APPENDIX - DISCUSSION OF PREVIOUS SAFETY ANALYSIS REPORTS . . . . . A A-1

TANK BREACH ................... . . . A-1

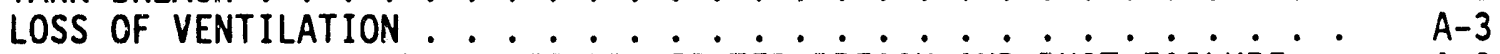

HIGH-EFFICIENCY PARTICULATE AIR FILTER BREACH AND DUCT FAILURE - A-3

APPENDIX REFERENCES .................. A-4 
WHC-EP-0373

\section{LIST OF FIGURES}

1 General High-Level Waste Tank Configurations at the Hanford Site . . 2

2 Hanford Site Map ..................... . 5

3 Hanford Tank Farm Facilities . . . . . . . . . . . . . . 6

4 Comparison of Hanford Site Response Spectra . . . . . . . . . . 8

5 Hanford Site High- and Moderate-Hazard Seismic Design

Response Spectra..................... 10

6 Summary Status of Hanford Site Waste Tank Seismic Qualification . . 12

\section{LIST OF TABLES}

1 Hanford Site Single-Shell Tank Seismic Evaluation Status . . . . . . 3

2 Hanford Site Double-Shell Tank Seismic Evaluation Status . . . . . . 4

A-1 Hanford Site Single-Shell Tank Isolation/Stabilization Status . . A-2 
WHC-EP-0373

\begin{abstract}
SUMMARY STATUS ON THE SEISMIC EVALUATIONS OF
HANFORD SITE RADIOACTIVE WASTE STORAGE TANKS
\end{abstract}

\title{
INTRODUCTION
}

Radioactive defense waste, resulting from the chemical processing of spent nuclear fuel, has been accumulating at the Hanford Site since 1944. This waste is stored in underground waste storage tanks. This paper provides a summary status of the seismic evaluations of the tanks and a summary of past safety assessments of the safety-related equipment that may be required to maintain safe operation subsequent to a postulated seismic event.

Five basic tank designs are used at the Hanford Site for underground liquid waste storage (Figure 1). Four of these designs are single shell; the fifth is a double-sheli tank design.

A total of 149 single-shell tanks (SSTs) were constructed between 1943 and 1964 (Table 1). These tanks are located in 12 separate groupings referred to as tank farms. One hundred thirty-three of the SSTs are $75 \mathrm{ft}$ in diameter with nominal capacities of 530,000 to $1,000,000 \mathrm{gal}$. Sixteen of the tanks are smaller units of a similar design with a 20-ft diameter and a capacity of 55,000 gal. The large SSTs are reinforced-concrete, cylindrical, dome-roofed, buried tanks with a single steel liner across the bottom and up the walls. Surface loads, static and dynamic soil loads, and hydrostatic and hydrodynamic loads are carried by the reinforced-concrete tank and dome. The steel 1 iner provides containment for the liquid waste.

A total of 28 double-shell tanks (DSTs) were constructed between 1968 and 1986 (Table 2). These tanks are located in six separate tank farms. The DSTs have a nominal capacity of one million gallons. The DSTs are $80-\mathrm{ft}$. diameter, reinforced-concrete, cy? indrical, dome-roofed, buried tanks with two steel liners. The primary steel liner consists of a floor, an independent 75-ft. diameter cylindrical shell, and a dome that is integral with the reinforced-concrete dome. The primary liner provides containment for the liquid waste. The secondary steel liner is attached to the inner surface of the reinforced-concrete tank wall and rests upon the concrete tank bottom. This secondary steel liner provides a redundant leakage barrier for containment of the liquid waste. The reinforced-concrete tank and dome iarry the surface loads and static ano dynamic soil loads. The primary steel iner resists the hydrostatic and hydrodynamic loads. There is a nominal 30-il. air gap between the primary steel tank and the lined reinforced-concrete tank wall.

The SST and DST tank farms are located on the Hanford Site in the 200 East and 200 West Areas (Figures 2 and 3). These facilities are operated by the Westinghouse Hanford Company for the U.S. Department of Energy-Richland Operations office. 


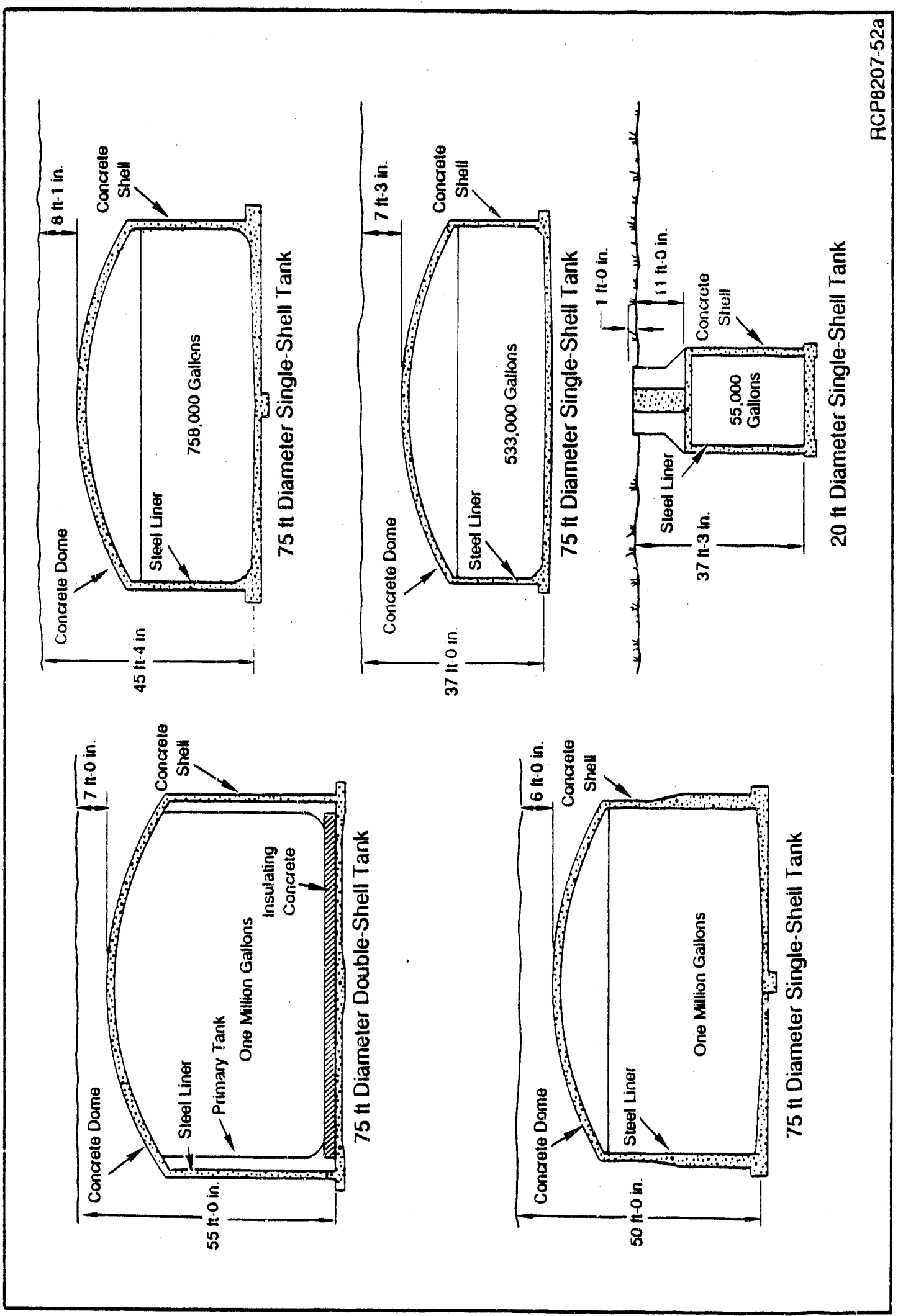

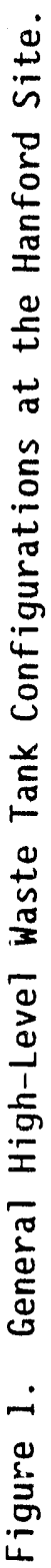


Table 1. Hanford Site Single-Shell Tank Seismic Evaluation Status.

\begin{tabular}{|c|c|c|c|c|c|c|c|}
\hline $\begin{array}{l}\text { Tank } \\
\text { Farm }\end{array}$ & $\begin{array}{l}\text { No. } \\
\text { of } \\
\text { Tanks } \\
\end{array}$ & $\begin{array}{l}\text { Date } \\
\text { Constr. }\end{array}$ & $\begin{array}{c}\text { Capacity } \\
\left(\times 10^{6}\right. \\
\text { gal }) \\
\end{array}$ & $\begin{array}{l}Z P A^{*} \\
(g)\end{array}$ & $\begin{array}{l}\text { Docu- } \\
\text { ment }\end{array}$ & $\begin{array}{c}\text { Evaluation } \\
\text { Criteria } \\
\text { Reference }\end{array}$ & Comment \\
\hline $241-A$ & 6 & $1954-55$ & 1.0 & 0.25 & 16 & 5,6 & \\
\hline 241-AX & 4 & $1963-64$ & 1.0 & 0.25 & 15 & 5,6 & \\
\hline $241-B$ & 16 & $1943-44$ & 0.5 & & & & $\begin{array}{l}\text { Four } 55,000- \\
\text { gal tanks }\end{array}$ \\
\hline 241-BX & 12 & $1946-47$ & 0.5 & & & & \\
\hline 241-BY & 12 & $1948-49$ & 0.75 & & & & \\
\hline $241-C$ & 16 & $1943-44$ & 0.5 & & & & $\begin{array}{l}\text { Four } 55,000- \\
\text { gal tanks }\end{array}$ \\
\hline $241-5$ & 12 & $1950-51$ & 0.75 & & & & \\
\hline 241-SX & 15 & $1953-54$ & 1.0 & & & & \\
\hline $241-T$ & 16 & $1943-44$ & 0.5 & & & & $\begin{array}{l}\text { Four } 55,000- \\
\text { gal tanks }\end{array}$ \\
\hline $241-T X$ & 18 & $1947-48$ & 0.75 & & & & \\
\hline 241-TY & 6 & $1951-52$ & 0.75 & & & & \\
\hline $241-U$ & 16 & $1943-44$ & 0.5 & & & & $\begin{array}{l}\text { Four } 55,000- \\
\text { gal tanks }\end{array}$ \\
\hline
\end{tabular}

Note: The Document and Criteria Reference numbers refer to the References (page 16) and Criteria References (page 19).

References: 15. RHO-R-6, 1978

16. ARH-R-121, 1972

bEvaluation Criteria: 5. ASME, Section VIII, Div. 2, 1974

6. ACI $318-71,1971$

$\star Z P A$ - zero-period acceleration 
Table 2. Hanford Site Double-Shell Tank Seismic Evaluation Status.

\begin{tabular}{ccccccc}
\hline $\begin{array}{c}\text { Tank } \\
\text { Farm }\end{array}$ & $\begin{array}{l}\text { No. } \\
\text { of } \\
\text { Tanks }\end{array}$ & $\begin{array}{c}\text { Date } \\
\text { Constr. }\end{array}$ & $\begin{array}{c}\text { Capacity } \\
\left(\times 10^{6}\right. \\
\text { gal) }\end{array}$ & $\begin{array}{c}\text { ZPA* } \\
(\mathrm{g})\end{array}$ & $\begin{array}{c}\text { Docu- } \\
\text { ment }\end{array}$ & $\begin{array}{c}\text { Criteria } \\
\text { Reference }\end{array}$ \\
\hline $241-A N$ & 7 & $1980-81$ & 1.144 & 0.25 & 22 & $5^{b}, 6^{b}$ \\
$241-A P$ & 8 & $1983-86$ & 1.144 & 0.25 & 21,26 & $7^{b}, 8^{b}$ \\
$241-A W$ & 6 & $1978-80$ & 1.144 & 0.25 & $20,22,24$ & $5^{b}, 6^{b}$ \\
$241-A Y$ & 2 & $1968-70$ & 1.00 & 0.25 & 17,25 & $1^{c}$ \\
$241-A Z$ & 2 & $1971-77$ & 1.00 & 0.25 & $18,22,25$ & $3^{b}, 4^{b}$ \\
$241-S Y$ & 3 & $1974-78$ & 1.144 & 0.25 & $19,22,23$ & $1^{b}, 2^{b}, 5^{b}$ \\
\hline
\end{tabular}

Note: The Document and Criteria Reference numbers refer to the References (page 16) and Criteria References (page 19).

References: 17. Holmes \& Narver HN-197, 1968

18. RHO-R-85, 1971

19. ARH-R-172, 1974

22. $\mathrm{RHO}-\mathrm{C}-17,1978$

23. RHO-C $-59,1981$

20. ARH-R-219, 1976

24. RHO-C $-60,1981$

21. American Bridge T-3036, 1983

25. SD-RE-TI-041, 1982

26. KEH R-82-21, 1982

Design Criteria: 1. ASME, Section III, Div. 1, 1971

2. ACI 318-63, 1963

3. AISC, Steel Construction Manual, 1970

4. ACI, Publication SP-3, 1965

5. ASME Section VIII, Div. 2, 1974

6. ACI $318-71,1971$

7. ACI 349-76, 1976

8. ASME Section VIII, Div. 2, 1980

'Evaluation Criteria: 1. ASME, Section III, Div. 1, 1971

$\star Z P A$ - zero-period acceleration 


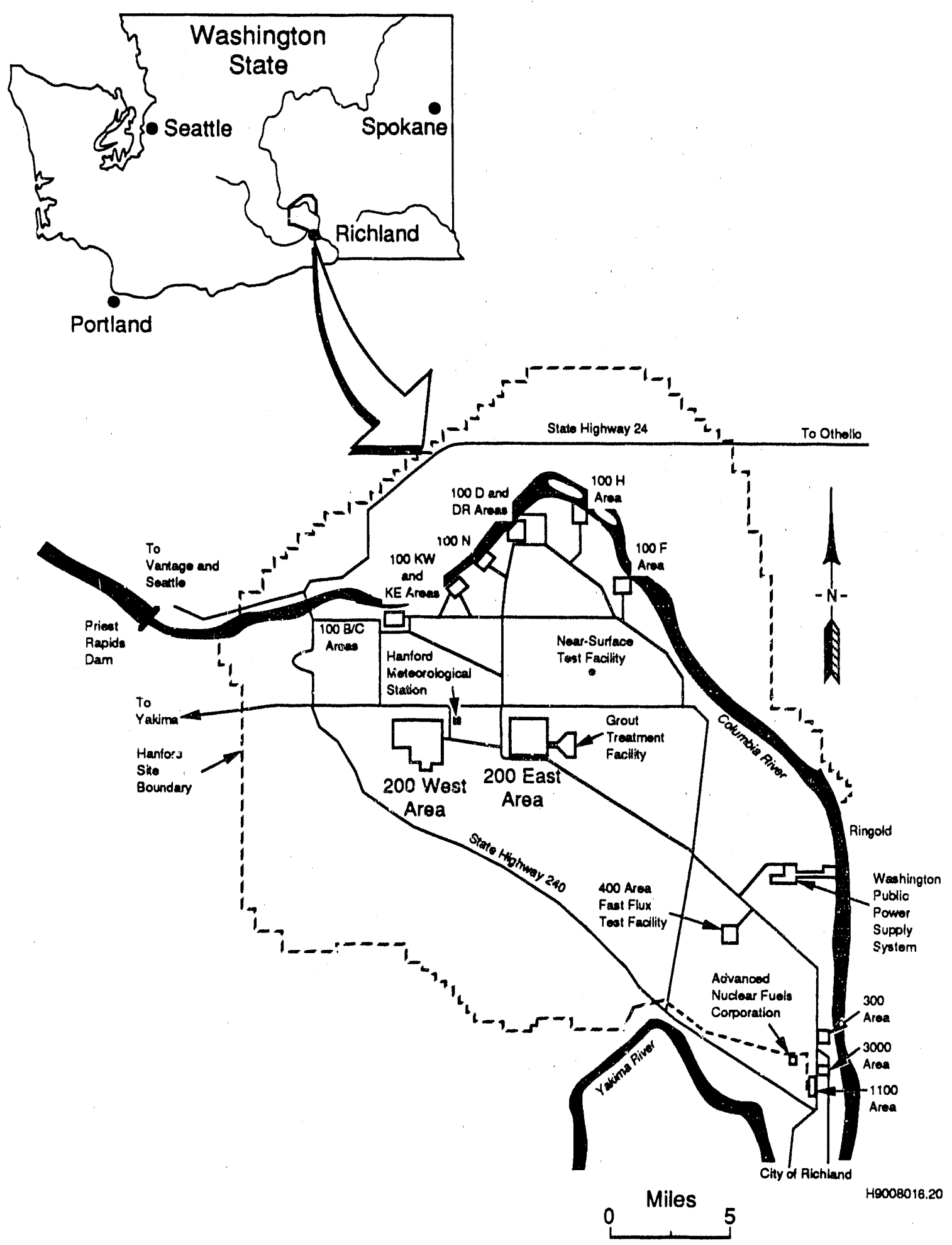

Figure 2. Hanford Site Map. 
WHC-EP-0373

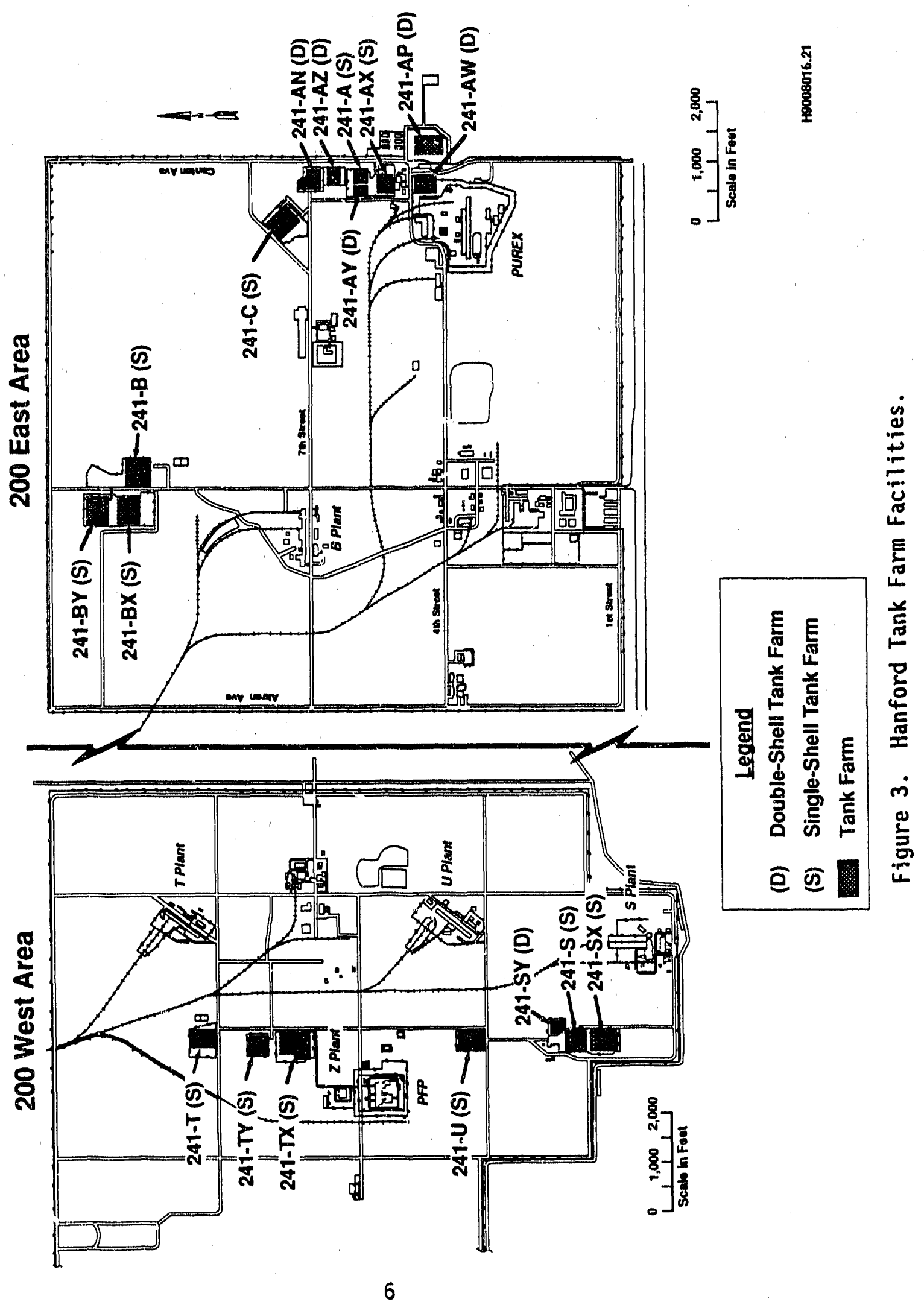


WHC-EP-0373

Both single-shell and double-shell underground waste tanks have ventilation system ducting to transport the contaminated tank waste vapors to high-efficiency particulate air (HEPA) filtration systems. Support facilities may include cooling water and emergency power supply systems for some tank farms.

A11 DSTs and the 11 SSTs with high decay heat loads (greater than 40,000 BTU/h) have active ventilation systems (air-lift circulation and condensers on the aging-waste tanks and electrical powered exhausters through HEPA filters). The remaining SSTs have passive ventilation through HEPA filters.

\section{SEISMIC DESIGN CRITERIA}

The Hanford Site is located in the Pasco Basin in the Intermontane Plateau Physiographic Province. The Site is an area of low-magnitude seismicity that has been instrumentally monitored since 1969. The historical record of felt earthquakes goes back to about 1850; however, these early records are anecdotal. Seismotectonic studies were completed for the design and construction of the Fast Flux Test Facility (FFTF) (refs. 1, 2, and 3). Thase studies culminated in a site-specific seismic design response spectra (Figure 4) anchored at $0.25-g$ peak horizontal ground motion. The FFTF was not licensed by the U.S. Nuclear Regulatory Commission (NRC); however, the NRC did review the final safety analysis report (ref. 4). The FFTF seismic design criteria were incorporated into the Hanfurd Plant Standards "ArchitecturalCivil Design Criteria," Standard Design Criteria (SDC) 4.1, Revision 6, in November 1973 (ref. 5). All waste tank analytical evaluations discussed in this report refers to the FFTF response spectra of Figure 4 .

Washington Public Power Supply System completed studies for the licensing and operation of a nuclear power reactor approximately $3.5 \mathrm{mi}$ $(5.5 \mathrm{~km})$ from the FFTF on the Hanford Site. The design basis peak horizontal ground motion for this plant is also $0.25 \mathrm{~g}$ (refs. 6, 7, and 8). Other recent seismotectonic studies on and around the Hanford Site include the Preliminary Safety Analysis Report (PSAR) for the Skagit/Hanford Nuclear Plants (ref. 9) and the Hanford Site Characterization Plan-Consultant Draft (ref. 10). The characterization plan summarizes data and seismotectonic interpretations of the Basalt Waste Isolation Project.

The FFTF seismic design criteria (Figure 4) were used for seismic qualification of safety-related equipment at the Hanford Site until September 9, 1989, when the SDC 4.1 was revised to incorporate recent Department of Energy (DOE) design guidance (refs. 11 and 12). A graded approach to the design of DOE non-reactor facilities was recommended, based on the hazard level of the facility. The postulated seismic load for a highhazard facility is equivalent to the 5,000-year earthquake and, for a moderate hazard, is equivalent to the 1,000-year earthquake. A median Newmark and Hall spectral shape is recommended by the DOE design guidance. 


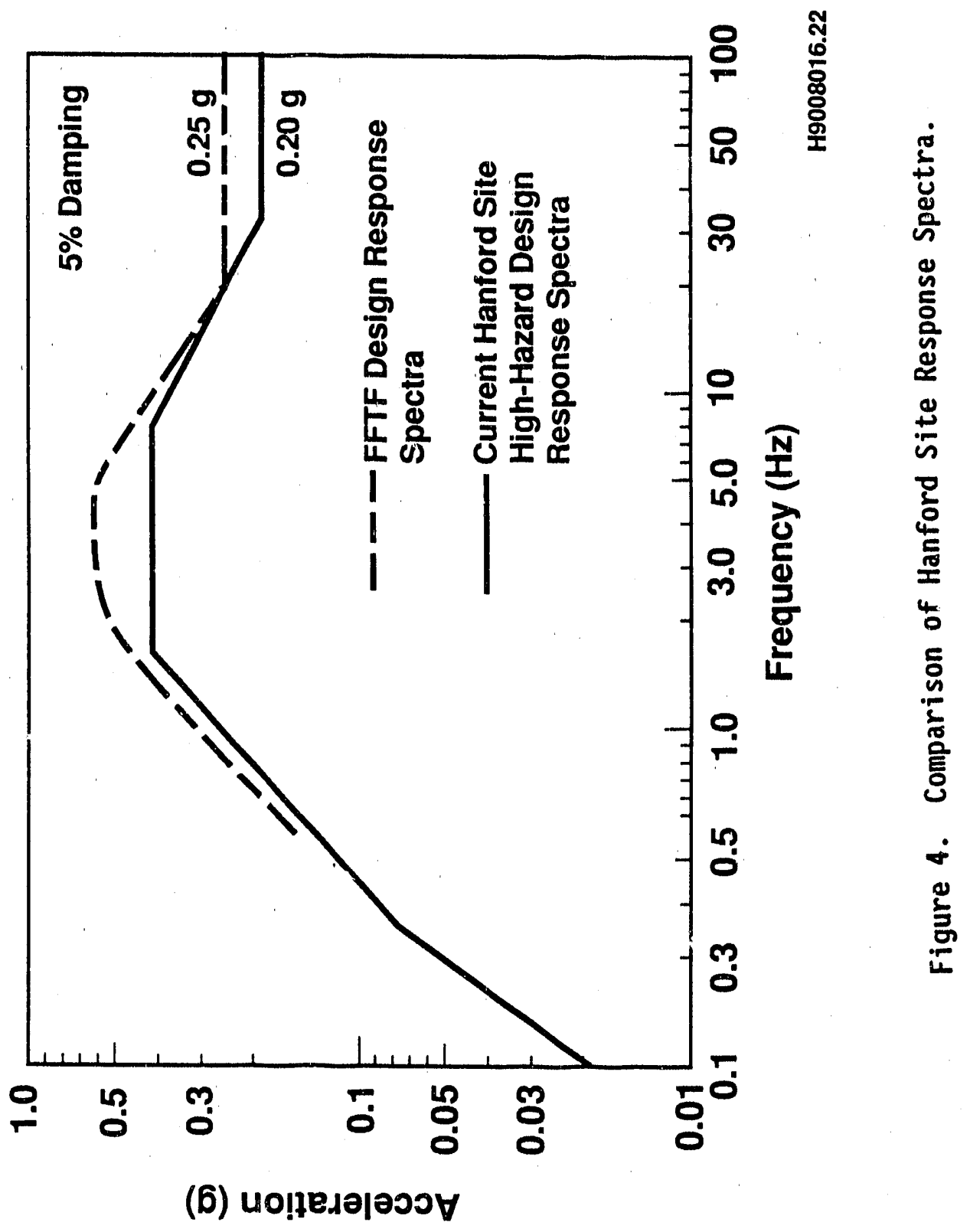


A probabilistic seismic hazard study was completed for the various facility locations on the Hanford Site (ref. 13) to determine the 5,000- and 1,000-year ground motions. Revision 11 of the SDC 4.1 (ref. 14) incorporates the DOE guidance and the results of the seismic hazard study. The response spectra for high- and moderate-hazard facilities are anchored to $0.20 \mathrm{-g}$ and $0.12-g$ peak horizontal ground motion, respectively, and are illustrated in Figure 5. The current high-hazard design spectrum is compared to the pre-1989 criteria in Figure 4.

\section{SOILS}

The soils in which the waste tanks are buried range from a sandy fine gravel to a coarse sand. The excavated sediments were used as backfill in the construction of the tanks. The water table or zone of saturation ranges from about 200 to $300 \mathrm{ft}(60$ to $90 \mathrm{~m})$ beneath the ground surface. Liquefaction of foundation materials during a seismic event is not considered to be a credible scenario because of the relatively coarse texture (grain size) of the soils, the relative density of the soils, and the significant depth to the water table (ref. 9). Although analyses have not been performed to assess the potential for liquefaction of foundation materials in the immediate vicinity of the tanks as a result of leakage, differential settlement of the tanks during a seismic event as a result of leakage is judged to be highly unlikely.

\section{SINGLE-SHELL TANK SEISMIC EVALUATIONS}

The SSTs were all designed and constructed before the development of the plant standardized seismic design criteria (refs. 5 and 14) and were built to the codes and standards in effect at the time they were designed. There have been two subsequent evaluations of SSTs to determine their seismic capacity.

The most recent and comprehensive seismic evaluation of SSTs was conducted in 1978 on the AX Tank Farm (ref. 15). The evaluation used the 0.25-g peak horizontal ground motion developed in 1971 for the FFTF (ref. 1) and later (1973) specified in the Hanford Plant Standards "Architectural-Civil Design Criteria," SDC 4.1 (ref. 5). A thermal load of $350^{\circ} \mathrm{F}$ and creep were considered. The evaluation qual ified the steel-1 ined, reinforced-concrete tank for seismic loads.

The evaluation of the A Tank Farm (ref. 16) was conducted in 1972, before the release of the SDC 4.1 seismic criteria (ref. 5); however, as part of that evaluation it was decided to seismically analyze the lined reinforcedconcrete tank to the $0.25 \mathrm{-g}$ horizontal ground motion. The ground motion used was the El Centro earthquake scaled to $0.25-9$ peak horizontal ground acceleration. This evaluation (ref. 16) assessed the seismic resistance of the steel-1ined, reinforced-concrete tank. 
WHC-EP-0373

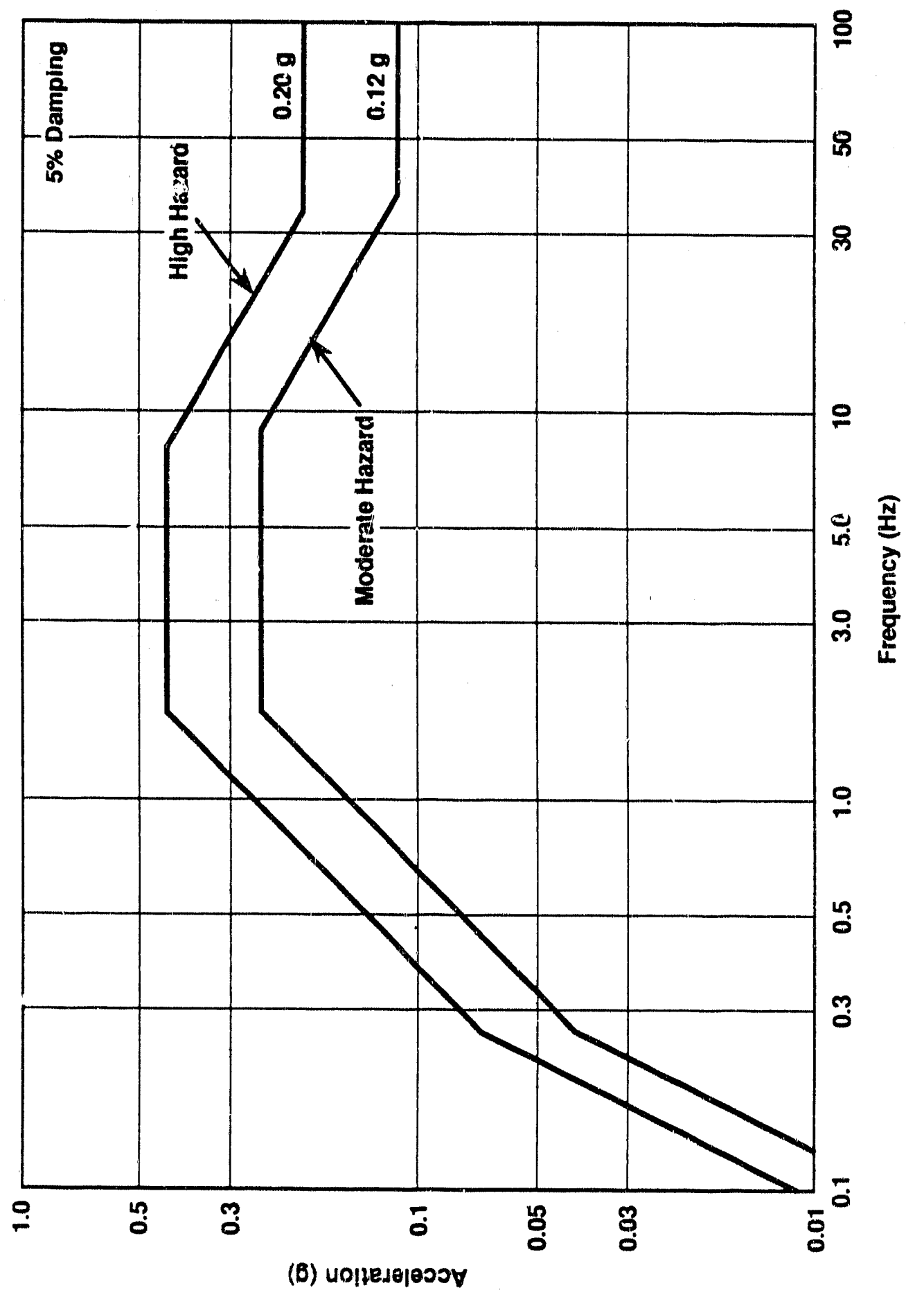

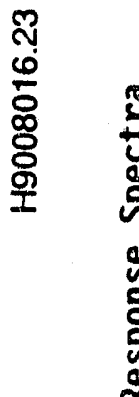

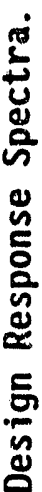

章

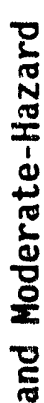

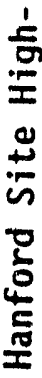

เ

尔 
WHC-EP-0373

Table 1 summarizes the status of the SST seismic evaluations. Figure 6 graphically illustrates the stabilization/isolation status and seismic evaluation status of all SSTs. Oniy the tanks in the $A$ and AX Tanik Farms have been explicitly seismically evaluated to $0.25 \mathrm{~g}$. However, the domed-roofed SSTs have the same dome gtometry and cylindrical section diameters. Only the height of the tank varies according to the capacity. The reinforcing steel is generally similar and only minor variations in structural detail exist. Because all SSTs were designed to the codes and standards of their day, and because the laigest capacity tanks, $A$ and $A X$, have been seismically evaluated for $0.25 \mathrm{~g}$, it is probable that analysis would qualify the remaining SST designs to the current high-hazard design specification of $0.20 \mathrm{~g}$.

\section{DOUBLE-SHELL TR̈NK SEISMIC EVALUATIONS}

Five of the six DST tank farms (AN, AP, AW, AZ, and SY, which inciude 26 of the 2.8 DSTs) were evaluated in their design phase for compliance with seismic design criteria. The site-specific seismic design criteria used in evaluating the AN, AP, AW, AZ, and SY Tank Farms used the 0.25-g peak horizontal ground motion developed in 1971 for the FFTF (ref. 1) and specified in SDC 4.1 in 1973 (ref. 5). The evaluations of these tanks considered both the lined reinforced-concrete tank for so:1 loads and the primary steel tanks for hydrostatic and hydrodynamic loads (refs. 17 through 26). Thermal loads and the effects of concrete creep for the tank contents at $350^{\circ} \mathrm{F}$ and $300^{\circ} \mathrm{F}$ were considered in references 24 and 26 , respectively. A maximum concrete thermal load of $350^{\circ} \mathrm{F}$ and the effects of creep were considered in reference 25. Whereas, the affects of solids and/or crust layer in the DSTs have not been accounted for in past analyses, these affects will be considered in planned future studies.

The sixth tank fim (AY), which was the first DST tank farm constructed, is of similar but not identical design. The evaluation of the AY Tank Farm was conducted in 1968 before completion of the FFTF and development of the SDC 4.1 (ref. 5) seismic criteria. The AY primary steel tank design was seismically evaluated to a $0.25-g$ horizontal ground motion (ref. 17). The ground motion used in the AY Tank evaluation was the El Centro earthquake scaled to $0.25-g$ peak horizontal ground acceleration. The reinforced-concrete tanks in the AY Farm have not specifically been seismically evaluated;

however, because of the similarity of the AY lined reinforced-concrete tank and dome to other SSTs and DSTs, the AY tank and dome are judged to be capable (ref. 25) of meeting the current seismic design criteria.

Table 2 summarizes the status of the DST seismic evaluations. A11 DSTs have been analyzed for $0.25 \mathrm{~g}$ (except the AY tanks). Only the primary steel liner of the AY tanks was evaluated fir $0.25 \mathrm{~g}$. Figure 6 graphically illustrates the status of the seismic evaluations of the DSTs. 

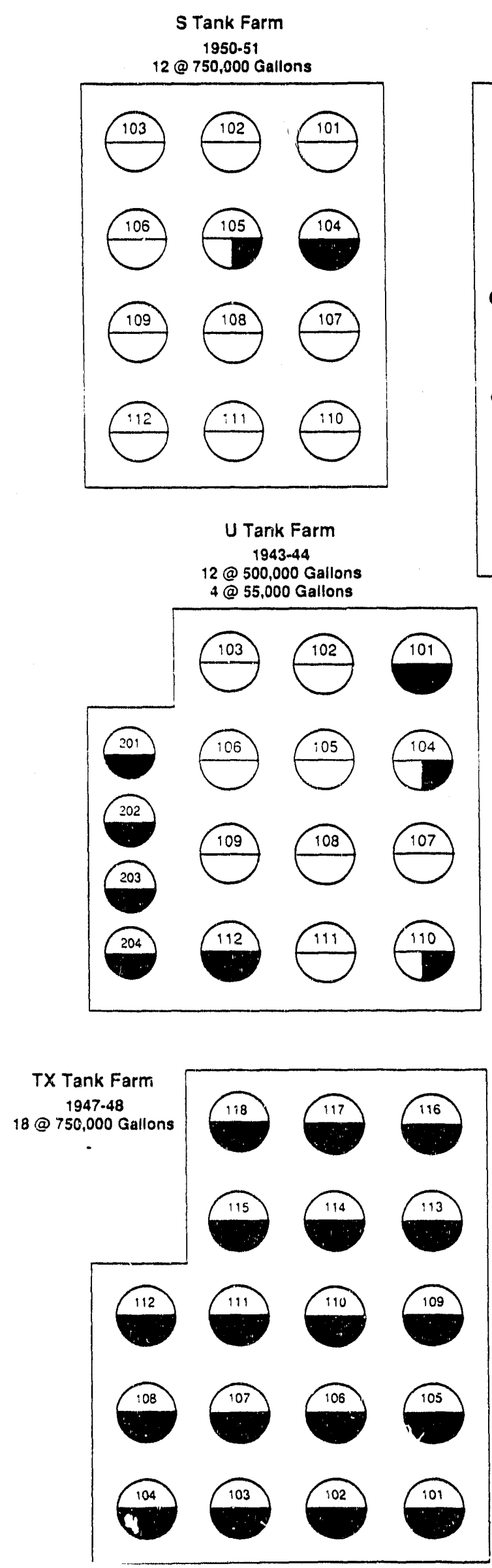

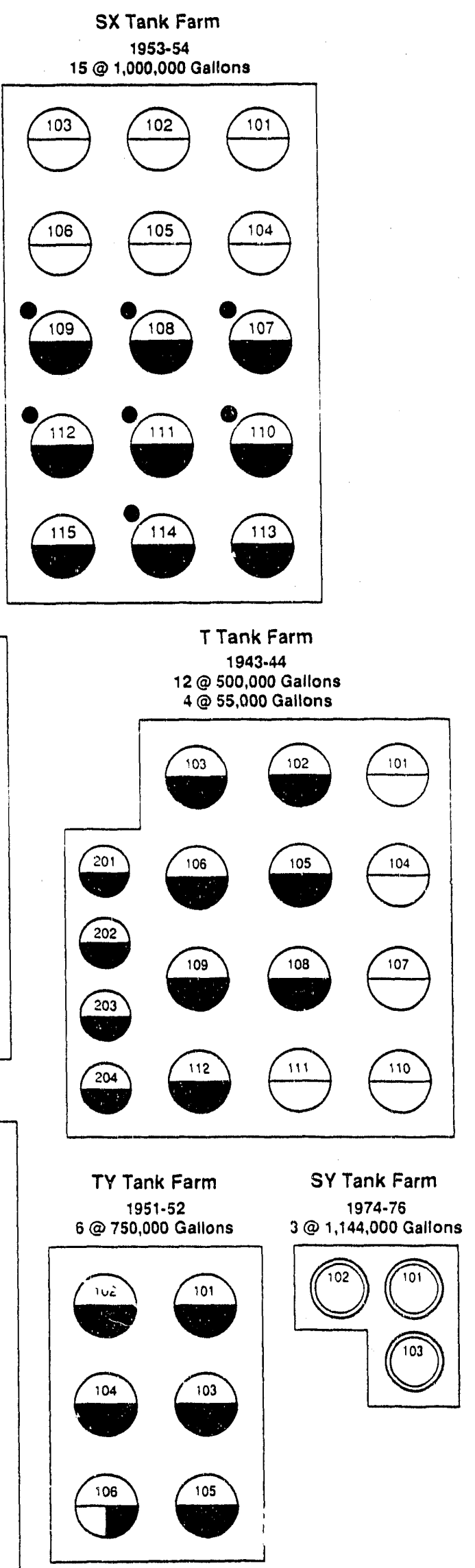

200 West Area Tanks 
WHC-EP-0373

A Tank Farm

1954.55

i@ 1,000,000 Galloris

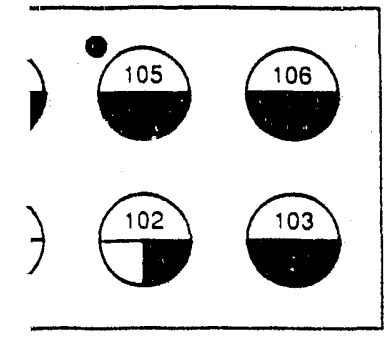

B Tank Farm

1943-44

$12 @ 500.000$ Gallons

$4 @ 55,000$ Gallons

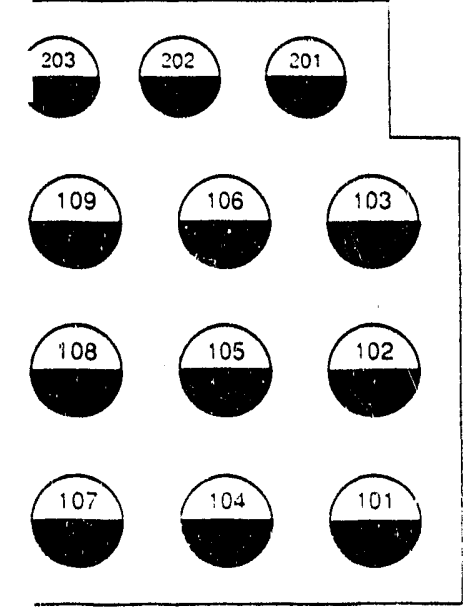

$m$

nks) (Aging-Waste Tanks)

llons 2 @ : $, 000,000$ Gallons

)

ary steel

cally

nalysis.

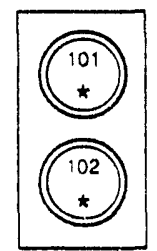

AX Tank Farm

1963-64

4 @ 1,000,000 Gallons

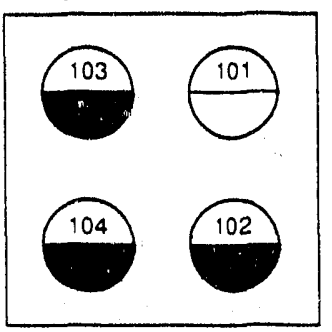

C Tank Farm

1943-44

$12 @ 500.000$ Gallons

4 (9) 55.000 Gallons

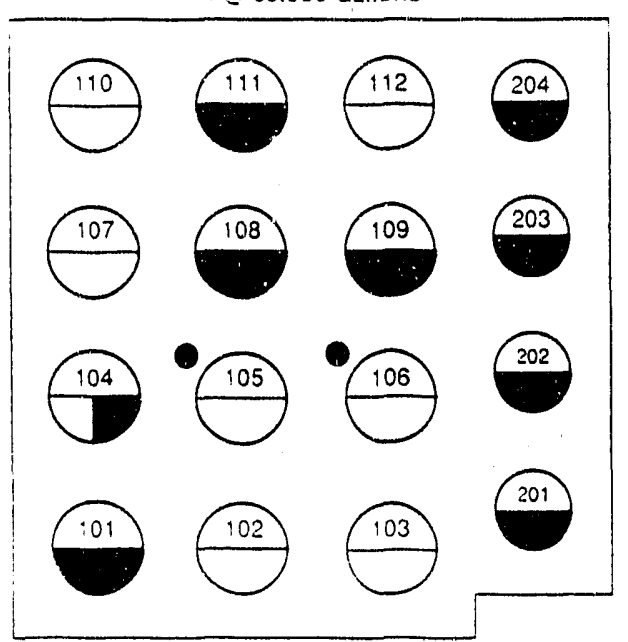

AW Tank Farm

1978-80

$6 @ 1,144.000$ Gallons

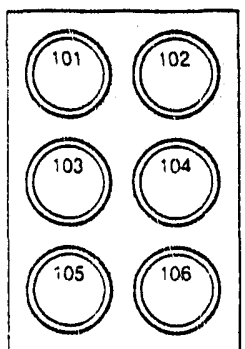

BX Tank Farm

1946-47

$12 @ 500,000$ Gallons

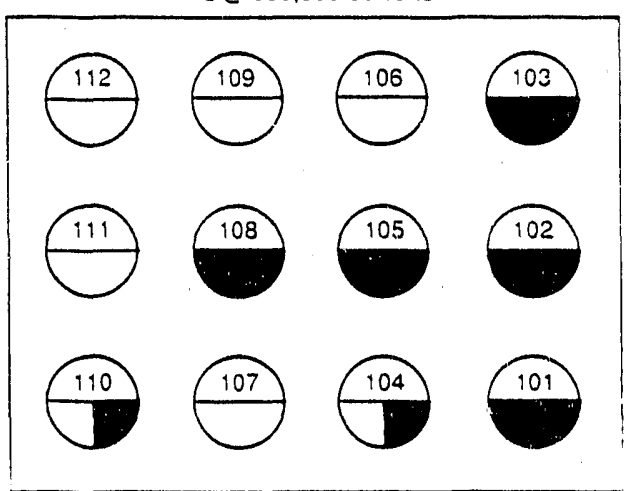

1948-49

$12 @ 750,000$ Gallons

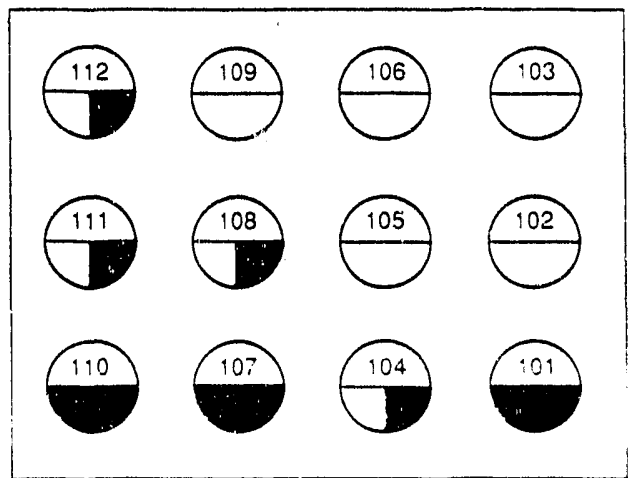

AP Tank Farm

1983-86

8 @ 1,144,000 Gallons

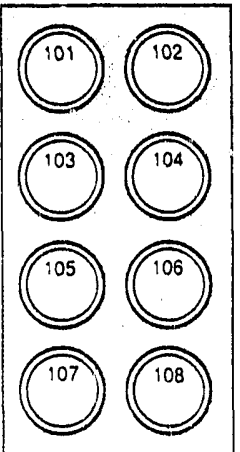

J0 East Area Tanks

anks

at load

nr)

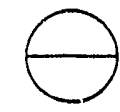

Partial Interim Isolated

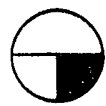

Partial Interim Isolated Interim

Stabilized

Interim Isolated Interim Stabilized

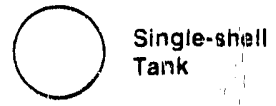

(C) Double-shell

00 All tanks located 0 in this tank farm are
seismically qualifiend

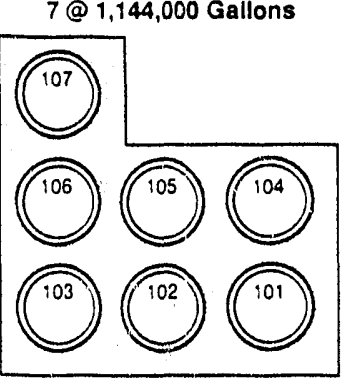

Figure 6. Summary Status of Hanford Site Waste Tank Seismic Qualification. 
WHC-EP-0373

\title{
WASTE TAMK SAFETY-RELATED EQUIPNENT
}

\begin{abstract}
Blume and Associates (refs. 27 and 28) provide an assessment of the $A$, $A X, A Y$, and $A Z$ ventilation systems for seismic loads. The site-specific seismic design criteria used in the evaluation of these ventilation systems is based on the $0.25 \mathrm{-g}$ peak horizontal ground motion developed for the FFTF and later specified in SDC 4.1 (ref. 5). Blume and Associates evaluated the vapor header system, de-entrainer, condensers, condensate storage tank, heater, ventilation ducts, filters, exhaust fans, and exhaust stack. The seismically induced stress in these components was found to be within allowable limits; thus, structural integrity is expected to be maintained. The development of a list of other components requiring seismic qualification will follow upon completion of the safety analysis report (SAR).
\end{abstract}

No seismic evaluations of safety-related equipment is available for other tank farms. The necessity for performing additional seismic analyses and evaluations depends on the results of ongoing and planned safety reviews and classifications. A discussion of information contained in previously prepared SARs (refs. 29, 30, 31, 32, and 33) for the waste storage tanks and safety-related equipment is provided in the Appendix.

\section{PLANNED ACTIVITIES}

In-depth reviews of currently available analyses have been initiated and will be continued throughout Fiscal Year 1991. A draft analysis review plan is now being prepared and will be enhanced and updated throughout Fiscal Year 1991. Efforts are underway to retrieve archived documentation. Once the archived documentation has been retrieved and examined, and the completeness of the documentation has been assessed, the review plan and schedule will be updated. For specific issues not adequately addressed (e.g., in situ conditions, aging, corrosion, sludge, crust layer, temperature effects, soil conditions, etc.), further evaluation activities will be identified, scheduled, and performed in accordance with the requirements of SDC 4.1, Revision 11 (ref. 14).

Development of the review plan will be coordinated with other tank assessment activities. These include safety analyses studies, environinental assessment and sampling work, structiral analyses to evaluate the hydrogen/ferrocyanide explosion potelitial breach of confinement, and project activities.

Ventilation system upgrades for the aging-waste tank farms (241-AY and 241-AZ) are now being developed. The safety class for systems to be upgraded has been established in accordance with the requirements of DOE Order $6430.1 \mathrm{~A}$ (ref. 11) as implemented in SDC 4-1, Revision 11 (ref. 14). These upgraded safety-related systems will be seismically qualified to the appropriate requirements of SDC 4.1 , Revision 11. Upgrades to the aging-waste tank farm SARs are planned and will be carried out in accordance with the requirements 
WHC-EP-0373

of DOE Order 6430.1A. The revised SARs will update the postulated accident scenarios and resulting consequences. These planned activities will be conducted in accordance with the allocation of funding.

\section{CONCLUSIONS}

Updated safety reviews of the SSTS, DSTs, and operating systems and equipment are to be performed. These safety reviews are expected to reaffirm the current understanding of what systems are safety related and identify any additional safety related systems. Based on current knowledge, except for the tanks, very few systems or equipment items are safety related. The specific safety related systems and equipment will then be seismically qualified to the requirements of SDC 4.1, Revision 11 (ref. 14).

\section{SINGLE-SHELL TANKS}

- The ten tanks in 241-A and 241-AX (75 ft in diameter, 1,000,000-gal capacity) have been seismically evaluated to $0.25 \mathrm{~g}$.

- Because of the similarities with respect to the SST design features, it is probable that the remaining SSTs can be seismically qualified to the current high-hazard design spectrum of $0.20 \mathrm{~g}$.

- Because they have been interim stabilized/interim isolated, 91 tanks are deemed to have minimized potential releases of radionuclides as a result of tank breach. (See the appendix.) A11 sixteen 55,000-gal capacity tanks have been interim stabilized/interim isolated.

\section{DOUBLE-SHELL TANKS}

- The lined reinforced-concrete tank and dome and the primary steel liner have been analytically demonstrated to meet the $0.25-\mathrm{g}$ spectra for all tanks except the 241-AY tanks.

- The primary steel liner of the 241-AY tanks has been analytically demonstrated to meet the seismic input spectra of $0.25 \mathrm{~g}$.

- Most of the key structural components of the AY tanks are of similar design to the other DSTs and are judged to be seismically qualified to the current seismic input spectra (ref. 14).

- Some of the key components of the 241-AY and 241-AZ ventilation systems (safety-related equipment) have been seismically evaluated by analysis. 
WHC-EP $-(1373$

\section{REFERENCES}

1. JABE-WADCO-03, A Summary Report - Seismic Evaluation and Development of Ground Accelerations and Response Spectra for FFTF Site, prepared by John A. Blume and Associates, Engineers, for the Hanford Engineering Development Laboratory, Westinghouse Hanford Company, 1971.

2. JABE-WADCO-02, Seismic Design Criteria for the Fast Flux Test Facility, Rev. 2, prepared by John A. Blume and Associates, Engineers, for the Hanford Engineering Development Laboratory, Westinghouse Hanford Company, Richland, Washington, July 1975.

3. JABE-WADCO-01, Seismic and Geologic Siting Evaluation Fast Flux Test Facility Near Richland, Washington, prepared by John A. Blume and Associates, Engineers, for Westinghouse Hanford Company, Richland, Washington, 1975.

4. NUREG-0358, Safety Evaluation Report for the United States Department of Energy Fast Flux Test Facility, U.S. Nuclear Regulatory Commission, Washington D.C., 1978.

5. DOE-RL Order 6430.1B, Hanford Plant Standards, "Standard Design Criteria (SDC) 4.1," Rev. 6, U.S. Department of Energy-Richl and Operations office, Richland, Washington, November 1973.

6. Washington Public Power Supply System, 1981, Final Safety Analysis Report, WPPSS Nuclear Project No. 2, Richland, Washington.

7. Washington Public Power Supply System, 1986, Final Safety Analysis Report, Nuclear Project Nos. 1 and 4, Richland, Washington.

8. NUREG-0892, Safety Evaluation Report Related to the Operation of WPPSS Nuclear Project No. 2, Supplement No. 1, U.S. Nuclear Regulatory Commission, Washington, D.C., 1982.

9. PSPL, 1982, Skagit/Hanford Nuclear Project, Preliminary Safety Analysis Report, Puget Sound Power and Light Company, Bellevue, Washington.

10. DOE/RW-0164, Consultation Draft Site Characterization Plan Reference Repository Location, Hanford Site, Washing un, U.S. Department of Energy, Washington, D.C., 1988.

11. DOE Order 6430.1A, General Design Criteria, U.S. Department of Energy, Washington, D.C., 1989.

12. Kennedy et al., 1988, Design and Evaluation Guidelines for Department of Energy Facilities Subjected to Natural Phenomena Hazards, R. P. Kennedy, S. A. Short, J. R. McDonald, M. W. McCann, and R. C. Murray, UCRL 1591ก, University of California Research Laboratory, Livermore, California. 
WHC-EP-0373

13. WHC-MR-0023, Evaluation of Seismic Hazard for Non-Reactor Facilities, Hanford Reservation, Hanford, Washington, prepared by Woodward-Clyde Consultants for Westinghouse Hanford Company, Richland, Washington, 1989.

14. DOE-RL Order 6430.1B, Hanford Plant Standards, "Standard Design Criteria (SDC) $4.1, "$ Rev. 11, U.S. Department of Energy-Richland Operations Office, Richland, Washington, May 1989.

15. RHO-R-6, Analysis of Underground Waste Storage Tank 241-AX at Hanford, Washington, prepared by URS/John A. Blume and Associates, Engineers, for Vitro Engineering, Richland, Washington, June 1978.

16. ARH-R-120, Final Report, Strength and Stress Analysis for Waste Tank Structures at Hanford, Washington, prepared by K. P. Milbradt, Illinois Institute of Technology for Atlantic Richfield Hanford Company, Richland, Washington, September 26, 1972.

17. HN-197, Report of Study of Hanford Waste Tank Structures, prepared by Holmes and Narver, Inc. for Atlantic Richfield Hanford Company, Richland, Washington, May, 1968.

18. ARH-R-85, Seismic Analysis of Underground Waste Storage Tanks 241-AZ-101 and -102 at Hanfoind, Washington, prepared by John A. Blume and Associates, Engineers, for Atlantic Richfield Hanford Company, Richland, Washington, April 1971.

19. ARH-R-172, Analysis of Underground Waste Storage Tanks 241-SY at Hanford, Washington, prepared by URS/John A. Blume and Associates, Engineers, for Atlantic Richfield Hanford Company, Richland, Washington, October 1974.

20. ARH-R-219, Analysis of Underground Waste Storage Tanks 241-AW at Hanford, Washington, prepared by URS/John A. Biume and Associates, Engineers, for Vitro Engineering, Richland, Washington, July 1976.

21. T-3036, Manufacturer's Design Report for Kaiser Engineers Hanford Company, Richland, Washington, and the United States Department of Energy Concrete Encased Steel Tanks for Tank Farm No. 241-AP, 200-East Area, Hanford Works, Richland, Washington, American Bridge Division, Engineering United States Steel Corporation, Pittsburgh, Pennsylvania, August 1983.

22. RHO-C-17, Additional Analyses of Underground Waste Storage Tanks 241-AW, Hanford, Washington, prepared by URS/John A. Blume and Associates, Engineers, for Vitro Engineering, Richland, Washington, May 1978.

23. RHO-C-59, Additional Analysis of Underground Waste Storage Tanks 241-SY, Hanford, Washington, prepared by URS/John A. Blume and Associates, Engineers, for Vitro Engineering, Richland, Washington, July 1981. 
24. RHO-C-60, A Comprehensive Summary of the Analysis of the 241-AW Underground Waste Storage Tanks, Hanford, Washington, prepared by URS/John A. Blume and Associates, Engineers, for Vitro Engineering, Richlind, Washington, July 1981.

25. RHO-SD-RE-TI-041, Thermal Creep and Uitimate Load Analyses of the 241-AY/AZ Reinforced Concrete Underground Waste Storage Tanks, F. R. Vollert, Rockwell Hanford Operations, Richland, Wastington, September 1982,

26. KEH, R-82-21, Stress Analysis and Structural Analysis 241-AF Tank Farm, prepared by Kaiser Engineers Hanford Company for Rockwe11. Hanford Operations, Richland, Washington, October 1982.

27. ARH-R-96, Phase I Seismic Review, 241-A Farm Waste Storage Tank Ventilation System at Hanford, Washington, prepared by John A. Blume and Associates, Engineers, for Atiantic Richfield Hanford Company, Richland, Washington, July 1971 .

28. ARH-R-116, Phase II Seismic Review, Waste Storage Tank Ventilation System, 241-A Farm, Hanford, Washington, prepared by John A. Blume and Associates, Engineers, for Atlantic Richfield Hanford Company, Richland, Washington, April 1972.

29. RHO-SD-WM-SAR-022, Nonstabilized Single-She1l Tank Hazards

Identification and Evaluation, D. A. Smith, Rockwell Hanford Operations, Richland, Washington, August 1986.

30. RHO-SD-WM-SAR-006, Single-Shell Tank Isolation Safety Analysis Report, Rev. 2, D: A. Smith, Rockwell Hanford Operations, Richland, Washington, February 1986.

31. RHO-SD-WM-SAR-007, Hazard Identification and Evaluation Core Sampling, R. L. Koontz, Rockwell Hanford Operations, Richland, Wastiington, June 1985.

32. RHO-SD-WM-SAR-016, Double-Shel1 Tank Farm Facility (241-AN, AW, AP, and SY) Safety Analysis Report, Rev. 1, R. L. Koontz, Rockwell Hanford Operations, Richl and, Washington, May, 1986.

33. RHO-SD-HS-SAR-010, Aging Waste Facility Safety Analysis Report, Rev. 2, D. J. Squires, Rockwell Hanford Operations, Richland, Washington, February 1987.

34. WHC-EP-0182, Tank Farm Surveillance and Waste Status Summary Report for July 1990, B. M. Hanlon, Westinghouse Hanford Company, Richland, Washington, November 1990. 


\section{CRITERIA REFERENCES (TABLES 1 AND 2)}

1. ASME Boiler and Pressure Vessel Code, Section III, Division 1, 1971 Edition, American Society of Mechanical Engineers, New York, New York.

2. Building Code Requirements for Reinforced Concrete (ACI 318-63), American Concrete Institute, Detroit, Michigan, 1963.

3. Steel Construction Manual, Seventh Edition, American Institute of Stee 1 Construction, New York, New York, 1970.

4. Reinforced Concrete Design Handbook: Working Stress Method, Third Edition, Publication SP-3, American Concrete Institute, Detroit, Michigan, 1965.

5. ASME Boiler and Pressure Vessel Code, Section VIII, Division 2, 1974 Edition, American Society of Mechanical Engineers, New York, New York.

6. Building Code Requirements for Reinforced Concrete (ACI 318-71), American Concrete Institute, Detroit, Michigan, 1971.

7. Code Requirements for Nuclear Safety Related Concrete Structures (ACI 349-16), American Concrete Institute, Detroit, Michigan, 1976.

8. ASME Boiler and Pressure Vessel Code, Section VIII, Division 2, 1980 Edition, American Society of Mechanical Engineers, New York, New York. 
WHC-EP-0373

\section{APPENDIX - DISCUSSION OF PREVIOUS SAFETY ANALYSIS REPORTS}

The following discussion and conclusions are based on information contained in the previously prepared safety analysis reports (SARs) for the waste storage tanks and safety-related equipment (refs. 1, 2, 3, 4, and 5j. These SARs address the consequences of seismically induced events that could result in tank breach, loss of ventilation (including electrical power), and high-efficiency particulate air (HEPA) filter breach and duct failure. The dose calculations presented in these SARs are based on the computer models in use at the time these studies were conducted. Present safety analysis guidelines require consideration of additional accident scenarios; for example, continuation of electrical power and abnormal ventilation flow. Safety studies are now being conducted and others are planned to update the existing safety analysis reports. The findings from these studies will confirm and/or supplement the existing safety analysis reports.

Potential chemical reactions in the waste storage tanks are being evaluated, which may result in different conclusions than are presented in the existing safety ana?yses. However, it is not anticipated that these evaluations would result in changes to the seismic qualification requirements.

Hydrogen buildup resulting from loss of ventilation was considered in reference 2. This analysis indicated that it would require 23 days for the tank with the largest inventory of radioactive material $\left(4 \times 10^{7} \mathrm{Ci}\right)$ to generate enough hydrogen so that the concentration in the dome would reach the lower flammability limit. From this analysis it was assumed that the hydrogen was not entrapped in the waste and was free to migrate into the tank vapor space. Future investigations may determine that the hydrogen could build up in the waste and exceed the lower flammability limit. If flow of hydrogen out of the tank as it is being generated (from diffusion and from tank breathing or active ventilation) is considered, or if the inventory is smaller, the time to reach the lower flammability limit is increased beyond 23 days. It was assumed that the tanks would be placed back on ventilation before this time elapses. Therefore, hydrogen generation was not considered to be a credible event that could result in an explosion that disperses tank waste (ref. 2 ).

\section{TANK BREACH}

The consequences resulting from a tank breach have not explicitly been calculated, but radionuclide concentrations could be expected to exceed drinking water standards in the ground water if the loss of liquid is substantial. This exceedance is calculated to occur in a few hundred to a few thousand years. The environmental impact statement for. Hanford Site defense waste (ref. 6) shows a negligible impact by the time the plume reaches the Columbia River. For those tanks that have been interim isolated and interim stabilized (Table A-1), the consequences of a tank breach are minimized because most of the drainable liquid has been removed. 
WHC-EP-0373

Table A-1. Hanford Site Single-Shell Tank Isolation/Stabilization Status.

\begin{tabular}{ll}
\hline Tank Farm & \multicolumn{1}{c}{ Interim Isolated/Interim Stabilized } \\
\hline $241-A$ & 103 through 106 \\
$241-A X$ & 102 through 104 \\
$241-B$ & A11 \\
$241-B X$ & 101 through 103, 105, and 108 \\
$241-B Y$ & 101,107, and 110 \\
$241-C$ & $101,108,109,111$, and 201 through 204 \\
$241-S$ & 104 through 115 \\
$241-S X$ & 107 th \\
$241-T$ & $102,103,105,106,108,109,112$, and 201 \\
$241-T X$ & through 204 \\
$241-T Y$ & A11 \\
$241-U$ & A11 \\
\hline
\end{tabular}

Of the remaining tanks, 44 are "partially interim isolated," and 14 tanks are "partial interim isolated/interim stabilized."

Interim Stabilized--A tank that contains less than 50,000 gal of interstitial liquid and less than 5,000 gal of supernatant liquid.

Interim Isolated--The completion of the effort to minimize the addition of liquids into an inactive storage tank. (Addition includes accidental intrusion of surface or ground water.)

Partial Interim Isolated--completion of the effort to interim isolate, except risers required for jet pumping/stabilization not yet isolated. 


\section{LOSS OF VENTILATION}

Calculations have shown that tanks with low heat loads (less than $40,000 \mathrm{Btu} / \mathrm{h})$ will not exceed the operational 1 imit of $350{ }^{\circ} \mathrm{F}\left(177^{\circ} \mathrm{C}\right)$ assuming no ventilation flow. The operational limit has been established at a level that will maintain structural integrity. All tanks having high heat loads (greater than $40,000 \mathrm{Btu} / \mathrm{h}$ ) are required to have active ventilation to maintain this temperature limit (see Figlire 6).

Campbell (ref. 8) presented calculations that showed that the temperature increased as a function of time in the event of loss of ventilation. Temperatures in tank $\mathrm{C}-106$ (heat rate $158,000 \mathrm{Btu} / \mathrm{h}$ ) could exceed $350^{\circ} \mathrm{F}\left(177^{\circ} \mathrm{C}\right)$ in the event that there was ventilation system failure and water was not periodically added to the tank to provide evaporative cooling. The time required for tank $\mathrm{C}-106$ to exceed $350^{\circ} \mathrm{F}\left(177^{\circ} \mathrm{C}\right)$ for this scenario is approximateiy 1 year. Tank $\mathrm{C}-106$ should be studied to determine the consequences of temperatures in excess of the operational limits. If the constquences exceed guidelines, and corrective measures cannot be taken within the appruximate 1-year time frame to prevent Tank $\mathrm{C}-106$ from exceeding the operational limit of $350^{\circ} \mathrm{F}$, the ventilation system will need to be seismically qualified.

The conclusions drawn for the 24 double-shell non-aging waste tanks are the same as those for SSTs because tne radioactive material inventories are similar. In fact, the tank with the highest heat load (not including agingwaste tanks) is an SST: tank C-106.

\section{HIGH-EFFICIENCY PARTICULATE AIR FILTER BREACH AND DUCT FAILURE}

Smith (ref. 2) describes an analysis of a postulated HEPA filter breach with continued exhaust flow. The event (applicable only to tanks with active ventilation as previously noted) could be caused by an earthquake if one assumes that the ventilation ducting remains intact, the fan remains running (it does not fail nor is electrical power lost) and the filter medium fails. Doses resulting from failure of the passive ventilation filter are similar but must be integrated over 7 days to reach the levels of the reference 2 scenario. Based on calculated dose consequences using current computer modeling techniques and safety acceptance criteria, the tank ventilation systems may need to be evaluated for seismic qualification requirements.

The consequences of a filter breach with assumed failure of the waste circulation system (the air-lift circulators) in the aging-waste tanks are expected to be less than those predicted in the existing SAR (ref. 5) because the $N$ Reactor is shut down and 180-day-cooled fuel is no longer being sent to the aging-waste tanks. The scenario evaluated was that the earthquake results in the failure of the ducts upstream of the HEPA filter, causing an unfiltered release from the tank. A detailed safety and waste dispersal analysis should be performed because no more 180-day-cooled waste is being added to the tank inventories. If the consequences exceed the current safety acceptance criteria and guidelines, then the ventilation system may have to be seismically qualified. 
WHC-EP-0373

\section{APPENDIX REFERENCES}

1. RHO-SD-WM-SAR-022, Nonstabilized Single-Shell Tank Hazards Ident ification and Evaluation, D. A. Smith, Rockwell Hanford Operations, Richl and, Washington, August 1986.

2. RHO-SD-WM-SAR-006, Single-Shell Tank Isolation Safety Analysis Report, Rev. 2, D. A. Smith, Rockwell Hanford Operations, Richland, Washington, February 1986.

3. RHO-SD-WH-SAR-007, Hazard Identification and Evaluation Core Sampling, R. L. Koontz, Rockwell Hanford Operations, Richland, Washington, June 1985 .

4. RHO-SD-WM-SAR-016, Double-She7l Tank Farm Facility (241-AN, AW, AP, and SY) Safety Analysis Report, Rev. 1, R. L. Koontz, Rockwel1 Hanford Operations, Richland, Washington, May, 1986.

5. RHO-SD-HS-SAR-010, Aging Waste Facility Safety Analysis Report, Rev. 2, D. J. Squires, Rockwell Hanford Operations, Richland, Washington, February 1987.

6. DOE/EIS-0113, Final Environmental Impact Statement - Disposal of Hanford Defense High-Level, Transuranic and Tank Wastes, Vols. 1-5, U.S. Department of Energy, Washington, D.C., 1987.

7. WHC-SD-WM-TI-431, Tank 101-SY Core Drilling Safety Evaluation Report, R. M. Marusich, Westinghouse Hanford Company, Richland, Washington, 1990.

8. RHO-LD-171, Heat Transfer Analysis for In Situ Disposal of Nuclear Waste in Single- and Double-Shell Underground Storage Tanks, G. D. Campbell, Rockwe11 Hanford Operations, Richiand, Washington, October 1981. 

